\title{
Fagutvikling i praksis
}

\author{
Fagutvikling er et viktig middel for å heve kompetansen i helsetjenesten, men krever ressurser, \\ metodekunnskap og samarbeid.
}

$\mathbf{S}$ pesialisthelsetjenestens kjerneoppgaver er diagnostikk og behandling av pasienter, utdanning av helsepersonell, forskning og utvikling (1). Helsepersonelloven stiller krav til personalet i forhold til forsvarlig utøvelse av klinisk arbeid, og spesialisthelsetjenesteloven krever at virksomhetene sørger for at helsepersonell får nødvendig utdanning for å utføre sitt arbeid forsvarlig. Et godt kunnskapsgrunnlag er selve grunnmuren i helsetjenesten. Det forutsetter at både ansatte og ledere må holde seg faglig oppdatert for å utøve en forsvarlig helsetjeneste. Men hvilken plass har fagutvikling i den kliniske hverdagen?

\section{Nye krav}

De siste ti årene har jeg arbeidet med ulike FoU-oppgaver knyttet til fagutvikling og kompetanseutvikling blant personalet på sengeposter. Min erfaring er at det skjer mye fagutvikling på de ulike enhetene, men at det ikke alltid er planlagt, systematisert eller dokumentert. Spesialisthelsetjenesten har i løpet av de siste ti årene opplevd endringer av arbeidsmetoder, teknologi og organisering, og samtidig fått strammere økonomiske rammer. Dette stiller nye krav til personalet om kompetanse, kvalitet og effektivitet. En annen utfordring er at personalet ofte består av mange ulike faggrupper med forskjellig utdanning. Økonomiske ressurser og lite tid ut over direkte pasientarbeid begrenser også hva som er mulig å iverksette. Mitt inntrykk er at personalet mener det er viktig med fagutvikling, men at dette ikke blir prioritert fordi det ikke finnes nok ressurser eller ikke er tradisjon for å jobbe systematisk med fag- og kompetanseutvikling. Sykehuspersonale mangler tradisjonelt kompetanse på og erfaring med metodekunnskap (2). Skal vi utvikle sykepleiefaget og øke medarbeidernes kunnskap, må vi prioritere dette.

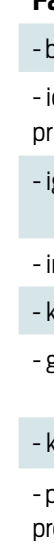

\section{Hva er fagutvikling?}

I dagligtalen er fagutvikling et «sekkebegrep» vi bruker om endringer som skjer i praksis og som er besluttet gjennomført. Begrepet brukes 


\section{Kompetanseutvikling}

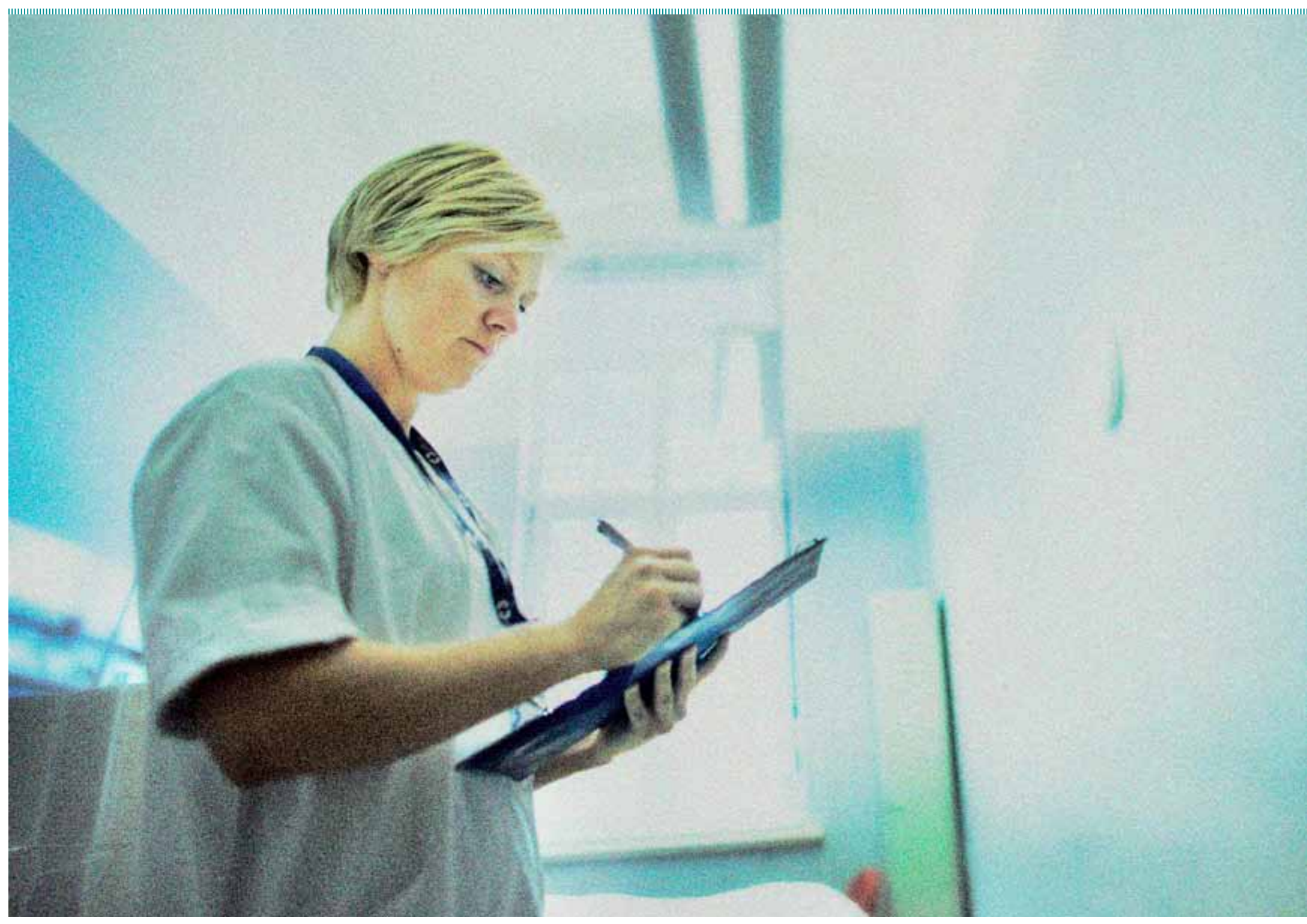

NøKKELROLLE: Den enkelte ansatte spiller en sentral rolle i fagutvikling ved arbeidsplassen. Arkivfoto: Bo Mathisen

mulere og utnytte deres kompetanse. Hver enkelt medarbeiders teoretiske kunnskap, yrkesspesifikke ferdigheter og personlige kompetanse utgjør til sammen personalets samlete kompetanse (8).

\section{Kompetanseplan}

Kompetanseplaner kan være et godt hjelpemiddel for planlegging og iverksetting av fagutvikling (6). Kompetanseplanlegging er en bevisst

\section{«Arbeidsplassens viktigste ressurs er personalet.»}

prosess som tar utgangspunkt i både ytre krav og forventninger (4). En kompetanseplan er et verktøy for å få en oversikt over eksisterende kompetanse og hva man ønsker å utvikle. I en kompetanseplan bør det komme tydelig frem hvem som har ansvar for å gjennomføre de ulike tiltakene i planen. Det krever en god struktur for hvordan man organiser arbeidsoppgaver, rutiner og planlegger turnus.

\section{Ansvar}

Ansvar for fagutvikling ligger hos enhetsledere, men mange poster har delegert dette til en egen person som har dette som sin spesialoppgave; assisterende enhetsleder, fagutvikler eller fagutviklingssykepleier. I en travel hverdag, hvor enhetsledere har mange oppgaver, vil en slik fordeling av arbeidsoppgaver kunne legge til rette for målrettet arbeid med kompetanseoppbyggende tiltak (9). For å få dette til å fungere best mulig bør det integreres i postens rutiner, og prioriteres både av ledere og personalet.

\section{Metoder}

Det er mange måter å arbeide med fagutvikling på. Metoden man velger avhenger av hva man skal vektlegge og utvikle kunnskap i forhold til. Metoder som ofte brukes er ulike former for undervisning, veiledning eller prosjekter.

Undervisning blir ofte valgt for å utvikle kompetansen hos personalet internt på posten. Men, undervisning er ikke ensbetydende med læring og endring. Det er mange forhold som påvirker dette. Motivasjon, interesse, forkunnskaper og holdninger påvirker læringsresultatet (10). Det er individuelt hvor lang tid det tar å lære seg noe (11). I tillegg skal man kunne anvende kunnskapen i klinisk arbeid. E-læringsprogrammer kan være et godt hjelpemiddel sammen med tradisjonelle metoder som undervisning, gruppearbeid eller litteraturstudie. Dialogundervisning som kombinerer både teori og refleksjon er en annen metode som kan være hensiktsmessig å bruke (12). Det er også viktig å ta utgangspunkt i personalets kompetansenivå når man planlegger undervisningen, slik at flest mulig får tilegnet seg ny kunnskap. Undervisning som ikke er tilpasset personalets behov eller faglige nivå, kan virke mot sin hensikt hvis nivået ligger for høyt eller blir for elementært (13).

Veiledning er en nyttig fagutviklingsmetode. Veiledning gir rom for å reflektere over egne erfaringer og følelser i møte med pasienter, og kan bidra til å finne løsninger på utfordringer og problemer på en slik måte at man kan få økt innsikt, forståelse og kunnskap (14). Veiledning kan bidra 
organisering krever god struktur og planlegging både før, under og etter gjennomføring.

\section{Utfordringer}

Det er mange ulike utfordringer rundt det å arbeide systematisk med fagutvikling på postnivå. Det er vesentlig at personalet er bevisste på at de har et eget ansvar for kompetanseheving og at de har evne til å planlegge ulike oppgaver. I tillegg er det viktig at man tilrettelegger for å gjennomføre fagutviklingstiltak (9). Et system som har gode strukturer for å ivareta pasienter og personale og samtidig prioriterer fagutvikling, vil kunne sikre et mer kompetent personale og bedre kvalitet på behandlingstilbudet.

Metodekunnskap er avgjørende for å arbeide med fagutviklingsoppgaver. For å ivareta dette har vi i Avdeling for psykosebehandling og rehabilitering etablert et fagutvikingsforum to ganger $\mathrm{i}$ halvåret der vi diskuterer fag. Forumet er en felles møteplass for ledere og personale på postene som har fagutviklingsoppgaver, hvor de kan utveksle erfaringer og diskutere faglige spørsmål. For å gi personalet mer metodekunnskap, er det utarbeidet en veileder for personalet i bruk av ulike fagutviklingsmetoder (6).

Endringsstrategier er en annen utfordring i fagutvikling. Personalet er den viktigste brikken i fagutviklingsarbeid. En viktig lederoppgave er å tilrettelegge og skape et godt miljø for utvikling og endring, og ivaretakelse av personalet er en sentral lederoppgave i denne sammenhengen (19). Endringer kan ofte skape usikkerhet og oppfattes som en trussel av personalet. Det er viktig å legge til rette for åpen dialog mellom personalet og ledelsen underveis i prosessen (2). Et godt arbeidsmiljø bidrar til at personalet opplever trygghet i eget arbeid, og til at de kan oppleve endringer som noe positivt (13). Mange har erfart at prosjekter har vært igangsatt uten at man har klart å gjennomføre det som var intensjonen. Ofte kan endringsprosesser sammenfalle med andre viktige utviklingsprosesser i en og samme enhet, slik at prosessene konkurrerer med hverandre eller ikke blir videreført (20). Det er viktig å sette av nok tid til å tilegne seg ny kunnskap i en organisasjon. Det kan ta opptil tre til fem år før ny praksis er integrert (21).

Implementering av ny kunnskap eller rutiner og å få til varige endringer kan være en utfordring (2). Mange gode tiltak har blitt avsluttet uten at man har klart å implementere tiltaket. Uklare mål, dårlig ledelsesforankring, mangel på ressurser og stramt tidsskjema er ofte de vanligste hindringene for en vellykket implementering (2).

\section{Avslutning}

Et godt kunnskapsgrunnlag er selve grunnmuren i helsetjenesten, og det er mange måter å forstå og arbeide med fagutvikling på. For å få til gode faglige utviklingsprosesser, er det viktig å øke kompetansen om hvordan man kan arbeide med fag- og kompetanseutvikling. Økt kunnskap og bruk av ulike undervisningsmetoder, veiledning satt i system og kunnskap om prosjektorganisering på postnivå vil være nyttige redskaper i den kliniske hverdagen. Systematisk fagutviklingsarbeid er viktig for å heve sykepleien, både faglig og kvalitetsmessig. Dette er et viktig lederansvar. Tilrettelegging, prioritering og planlegging er avgjørende for å få til gode utviklingsprosesser. Hvor god behand-

\section{«Veiledning er en nyttig fag- utviklingsmetode.»}

ling og oppfølging pasientene får, er avhengig av hvor dyktig hver enkelt medarbeider er. Kompetanseutvikling bør derfor omfatte både hver enkelt medarbeider og posten eller avdelingen som helhet. $\varnothing \mathrm{kt}$ fagutvikling vil gi dyktigere medarbeidere og bedre pasientbehandling. IIII

\section{LITTERATURLISTE:}

1. Norges offentlige utredninger. Pasienten først! - ledelse og organisering sykehus. NOU 1997: 2. Oslo: Sosial- og helsedepartementet, 1997. 2. Sørås I. Organisasjonsutvikling i sykehus: Oslo: Universitetsforlaget 2007. 3. www.ordnett.no. (3.11.2011).

4. Lai L. Strategisk kompetansestyring. Bergen: Fagbokforlaget, 2006. 5. St.meld. nr. 28 (1988-89) Helse og omsorgsdepartementet. Om Forskning. 6. Løvsletten M. Fagutvikling, veileder i metoder og muligheter. Sykehuset Innlandet 2010.

7. Nortvedt M, Jamtvedt G, Graverholt B, Reinar LM. Å arbeide og undervise kunnskapsbasert. Oslo: Norsk Sykepleierforbund, 2007.

8. Skau GM. Gode fagfolk vokser - Personlig kompetanse i arbeid med mennesker:

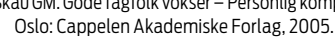

Oslo: Cappelen Akademiske Forlag, 2005.
9. Christensen B, Carlsen TC, Jensen K. Fagutviklingssy kepleieren som brobygger mellom forskning og klinisk praksis. Sykepleien Forskning 2009; 2: 100-106.
mat. mellom forskning og klinisk praksis. Sykepleien Forskning
Bjørklund B. A være lærer for voksne. Oslo: Cappelen, 1999.

10. Bjørklund B. A være lærer for voksne. Oslo: Cappelen, 1999.
11. Dalin $\AA$. Veier til den Lærende organisasjon. Oslo: Cappelen Akademiske ForLag, 1999.

12. Nysveen K, Nordby K, Brattrud TL, Granrud A. Miljøterapi i psykisk helsevern - et prosjekt verdig. Vallset: Oplandske Bokforlag, 2011

13. Larsen RP. Teamutvikling - teambygging og teamarbeid. Oslo: Cappelen akademisk forlag, 2007.

14. Tveiten S. Veiledning - mer enn ord. Bergen: Fagbokforlaget, 2005

15. Svendsen I. Veiledning som helsefremmende bidrag. Masteroppgavei rådgiving Trondheim: NTNU, 2011 .

16. Aasebø Hauken M. Hva er et godt prosjektarbeid, Sykepleien 2009; 17: 62-65. 2009.

17. Jessen SA. Prosjektledelse trinn for trinn - En håndbok i ledelse av små og mellomstore prosjekter. Oslo: Universitetsforlaget, 2008

18. Aasebø Hauken M. Sykepleier som prosjektleder. Sykepleien 2010; 1: 55-57.

19. Martinsen ØL. Perspektiver på ledelse. Gyldendal Akademiske, 2004.

20. Løvsletten M. Evalueringsrapport Ambulant Dobbeltdiagnoseteam 20042007. Sykehuset Innlandet 2008.
200

21. Bastøe $P \emptyset$, Dahl K, Larsen E. Organisasjoner i utvikling og endring. Oslo: Gyldendal forlag 2002

Fagartikler kan sendes til torhild.apall@sykepleien.no målet med prosjektet, og hvor lenge det skal vare. Valg av prosjektleder er også viktig (18). Prosjekt- 